This item was submitted to Loughborough's Research Repository by the author.

Items in Figshare are protected by copyright, with all rights reserved, unless otherwise indicated.

\title{
An in situ powder neutron diffraction study of nano-precipitate formation during processing of oxide-dispersion-strengthened ferritic steels
}

PLEASE CITE THE PUBLISHED VERSION

http://dx.doi.org/10.1016/j.jallcom.2013.08.069

PUBLISHER

(C) Elsevier

VERSION

AM (Accepted Manuscript)

\section{PUBLISHER STATEMENT}

This work is made available according to the conditions of the Creative Commons Attribution-NonCommercialNoDerivatives 4.0 International (CC BY-NC-ND 4.0) licence. Full details of this licence are available at: https://creativecommons.org/licenses/by-nc-nd/4.0/

\section{LICENCE}

CC BY-NC-ND 4.0

\section{REPOSITORY RECORD}

Zhang, Hongtao, Michael J. Gorley, Kok Boon Chong, Michael E. Fitzpatrick, Steve G. Roberts, and Patrick S. Grant. 2013. "An in Situ Powder Neutron Diffraction Study of Nano-precipitate Formation During Processing of Oxide-dispersion-strengthened Ferritic Steels”. Loughborough University. https://hdl.handle.net/2134/17739. 


\title{
An in-situ powder neutron diffraction study of nano-precipitate formation during processing of oxide-dispersion-strengthened ferritic steels
}

\author{
Hongtao Zhang, ${ }^{\mathrm{a},}{ }^{*}$ Michael J. Gorley, ${ }^{\mathrm{a}}$ Kok Boon Chong, ${ }^{\mathrm{b}}$ Michael E. Fitzpatrick, ${ }^{\mathrm{b}}$
}

Steve G. Roberts ${ }^{\mathrm{a}}$ and Patrick S. Grant $\mathrm{a}^{\mathrm{a}}$

${ }^{a}$ Department of Materials, University of Oxford, Parks Road, Oxford OX1 3PH, UK

${ }^{\mathrm{b}}$ Materials Engineering, The Open University, Walton Hall, Milton Keynes MK7 6AA, UK

\begin{abstract}
The evolution of phases in a Fe- $14 \mathrm{Cr}-10 \mathrm{Y}_{2} \mathrm{O}_{3}$ (wt.\%) oxide-dispersion-strengthened ferritic steel during mechanical alloying (MA) and subsequent annealing was studied by high resolution powder neutron diffraction, with emphasis on the kinetics of oxide-based nanoprecipitate formation. $\mathrm{Y}_{2} \mathrm{O}_{3}$ particles were almost dissolved into the ferritic matrix during MA. The formation of nano-precipitates was then observed by in-situ thermo-diffraction experiments during annealing of as-milled powder above $900^{\circ} \mathrm{C}$, supported by scanning electron microscopy. This revealed nano-precipitate coarsening with increasing annealing temperature. Powder microhardness was measured at various processing stages, and hardness changes are discussed in terms of the measured phase fractions, crystallite size and lattice strain at different temperatures and times.
\end{abstract}

Keywords: Neutron diffraction; Mechanical alloying; Ferritic steels; Oxide-dispersionstrengthened (ODS) alloy; Precipitation. 
* Corresponding author. Tel.: +44 1865283714; fax: +44 1865848785.

E-mail address: hongtao.zhang@materials.ox.ac.uk 


\section{Introduction}

The increasing demand for energy coupled with a need to reduce carbon dioxide emissions associated with fossil fuels has revived interest in nuclear energy, the efficient and safe utilization of which will rely on improved neutron-resistant materials for use in nextgeneration fission and first-generation fusion power plants. Reduced-activation ferritic oxidedispersion-strengthened (ODS) steels are promising candidate materials because of their relatively stable high temperature mechanical properties and comparative resistance to neutron irradiation [1]. The superior performance over conventional equivalents is attributed to the presence of nanosized oxide dispersoids that act, even at very low volume fraction $(<1$ vol\%), as: (a) pinning points to dislocation movement giving high temperature strength and creep resistance; (b) nucleation sites for small helium bubbles, preventing formation of large bubbles, or excessive He migration to grain boundaries both of which lead to embrittlement; and (c) stable sinks for irradiation induced defects such as vacancies and interstitial atoms, reducing accumulation of hardening defects such as dislocation loops [1]. Therefore, understanding of oxide-based nano-precipitate (nanocluster) formation during ODS processing is critically important for optimisation of alloy-process combinations.

ODS steels are usually produced by powder metallurgy routes involving mechanical alloying (MA) of $\mathrm{Y}_{2} \mathrm{O}_{3}$ and pre-alloyed or elemental metallic powders followed by consolidation, such as hot isostatic pressing (HIP) or hot extrusion. The structure and chemistry of the nano-oxide particles in ODS steels have been investigated by using various techniques [2-11], based on which the commonly proposed mechanism for the formation of nano-oxide particles is that room temperature MA produces a supersaturated solid solution containing $\mathrm{Y}$, Ti and $\mathrm{O}$ which decomposes during high temperature consolidation to precipitate nano-oxide particles [1]. A 
brief review of some key findings that support this mechanism and the remaining uncertainties and limitations of techniques is discussed below.

Cayron et al. [2] reported that although $\mathrm{Y}_{2} \mathrm{O}_{3}$ particles could not be resolved by transmission electron microscopy (TEM) in as-milled Eurofer Fe-9Cr +0.2 or $1.0 \mathrm{Y}_{2} \mathrm{O}_{3}$ (mass percent, unless noted otherwise) steel powder, $\mathrm{Y}_{2} \mathrm{O}_{3}$ particles with a much finer distribution than the starting $\mathrm{Y}_{2} \mathrm{O}_{3}$ were clearly visible after HIPing. That $\mathrm{Y}_{2} \mathrm{O}_{3}$ particles are not resolved by TEM in as-milled ODS powder is widely reported, even when a high fraction (3-15\%) of $\mathrm{Y}_{2} \mathrm{O}_{3}$ is added $[3,4]$.

Kimura et al. [3] studied the microstructural evolution of $\mathrm{Fe}-24 \mathrm{Cr}-15 \mathrm{Y}_{2} \mathrm{O}_{3}$ during MA and subsequent annealing by X-ray diffraction (XRD) and TEM. It was found that $\mathrm{Y}_{2} \mathrm{O}_{3}$ particles were gradually fractured, decomposed and finally dissolved into the ferritic matrix at long milling times $(360 \mathrm{ks})$, with milled powder comprising a mixture of elemental $\mathrm{Fe}, \mathrm{Cr}$ and $\mathrm{Y}_{2} \mathrm{O}_{3}$. At the same time, the MA produced ultra-fine $(10-15 \mathrm{~nm})$ ferrite grains. After annealing above $1200 \mathrm{~K}$, re-precipitation of both $\mathrm{Y}_{2} \mathrm{O}_{3}$ and $\mathrm{YCrO}_{3}$ occurred, which also triggered the growth of matrix grains. Okuda et al. [4] showed by small angle X-ray scattering that the $\mathrm{Y}_{2} \mathrm{O}_{3}$ particles in $\mathrm{Fe}-13 \mathrm{Cr}-3 \mathrm{Ti}-3 \mathrm{Y}_{2} \mathrm{O}_{3}$ became smaller with the increasing milling time and effectively disappeared after attrition milling for $48 \mathrm{~h}$. They also showed that $\mathrm{Ti}$ promoted the dissolution process and more complex Ti-Y-O nano-precipitates $\left(\mathrm{Y}_{2} \mathrm{Ti}_{2} \mathrm{O}_{7}\right.$ and $\left.\mathrm{Y}_{2} \mathrm{TiO}_{5}\right)$ were formed during subsequent annealing at temperature above 1273 K.

Miller et al. [5,6] and Larson et al. [7] studied nanocluster formation in Fe-(12-14)Cr-3W$0.4 \mathrm{Ti}-0.3 \mathrm{Y}_{2} \mathrm{O}_{3}$ by atom probe tomography (APT). Neither nanoclusters nor remnants of the 
starting $\mathrm{Y}_{2} \mathrm{O}_{3}$ particles were resolved in as-milled powder. However, in extruded materials, a high number density of Ti-Y-O enriched nanoclusters with a much smaller size $(2 \mathrm{~nm})$ than that of starting $\mathrm{Y}_{2} \mathrm{O}_{3}$ powder $(\sim 20 \mathrm{~nm})$ was detected. Their observations supported the hypothesis that $\mathrm{Y}_{2} \mathrm{O}_{3}$ powder fully dissolves in the ferrite during $\mathrm{MA}$ and that there is a thermodynamic preference for Ti-Y-O based compound formation during consolidation. The $\mathrm{Y}$ and $\mathrm{O}$ concentrations detected by APT in the ferrite matrix from both as-milled Fe-14Cr$2 \mathrm{~W}-0.25 \mathrm{Ti}-0.2 \mathrm{Y}-0.05 \mathrm{O}$ powder [8] and consolidated $\mathrm{Fe}-12.3 \mathrm{Cr}-3 \mathrm{~W}-0.24 \mathrm{Y}_{2} \mathrm{O}_{3} / \mathrm{Fe}-12.3 \mathrm{Cr}-$ $3 \mathrm{~W}-0.39 \mathrm{Ti}-0.25 \mathrm{Y}_{2} \mathrm{O}_{3}$ materials [9] were significantly higher than the $\alpha$-Fe equilibrium levels, which indicated the formation of a supersaturated solid solution containing $\mathrm{Y}$ and $\mathrm{O}$ due to the dissolution of $\mathrm{Y}_{2} \mathrm{O}_{3}$ during MA.

Toualbi et al. [10] studied the evolution of $\mathrm{Y}_{2} \mathrm{O}_{3}$ in $\mathrm{Fe}-9 \mathrm{Cr}-10 \mathrm{Y}_{2} \mathrm{O}_{3}$ powder using neutron diffraction. $\mathrm{Y}_{2} \mathrm{O}_{3}$ was detected in unmilled powder, but not in $48 \mathrm{~h}$ milled powder. After annealing at $1100^{\circ} \mathrm{C}$ for $1 \mathrm{~h}$ and investigation at room temperature, a $\mathrm{Y}_{2} \mathrm{O}_{3}$ phase re-appeared. Alinger et al. [11,12] studied as-milled, annealed and HIPed Fe-14Cr based ODS powder by using small angle neutron scattering (SANS). The nanoclusters were absent in as-milled powder, due to $\mathrm{Y}_{2} \mathrm{O}_{3}$ dissolution into steel matrix during MA, but re-precipitated in annealed powder at $850^{\circ} \mathrm{C}$. These nanoclusters were essentially identical to those in HIP consolidated alloys. Increasing annealing or consolidation temperature resulted in larger nanocluster sizes and smaller number densities and volume fractions.

Zhong et al. [13] studied the precipitation kinetics of $\mathrm{Ti}_{2} \mathrm{Y}_{2} \mathrm{O}_{7}$ nano-precipitates in $\mathrm{Fe}-14 \mathrm{Cr}$ $1 \mathrm{~W}-0.3 \mathrm{Ti}-0.3 \mathrm{Y}_{2} \mathrm{O}_{3}$ by SANS and TEM. Ti-Y-O enriched nano-precipitates formed with a very small size of $1.4 \mathrm{~nm}$ and volume fraction of $0.4 \%$ in as-milled powder. Consolidation by hot extrusion at $1100^{\circ} \mathrm{C}$ induced slight growth of nano-precipitates to a bimodal particle size 
distribution with peaks at $1.4 \mathrm{~nm}$ and $5.2 \mathrm{~nm}$. Using X-ray absorption fine structure spectroscopy and TEM, He et al. [14] showed a complete dissolution of $\mathrm{Y}_{2} \mathrm{O}_{3}$ in as-milled Fe13.5Cr-2W-(0-0.4Ti) $-0.3 \mathrm{Y}_{2} \mathrm{O}_{3}$ powder. $\mathrm{Y}_{2} \mathrm{O}_{3}$ and $\mathrm{YCrO}_{3}$ coexisted in the Ti-free HIPed alloys with Ti-Y-O oxides in HIPed alloys containing Ti, suggesting that the addition of $\mathrm{Ti}$ did not facilitate $\mathrm{Y}_{2} \mathrm{O}_{3}$ dissolution, but changed the morphology and chemistry of nanoprecipitates in consolidated alloys.

While this brief review shows progress in understanding the dissolution and re-precipitation of nanoclusters, most of the prior studies are limited by two factors:

1) They are based on ex-situ characterization of the final material at the end of a multi-step consolidation process, so that the details of the early stages of nano-precipitate formation are impossible to recover;

2) The characterization techniques study only an extremely limited volume of material, so that representative behaviour is difficult to obtain and nano-scale variations in local chemistry could dominate the observed precipitation behaviour.

In this paper, we use high resolution powder neutron diffraction to study the progressive dissolution of $\mathrm{Y}_{2} \mathrm{O}_{3}$ during $\mathrm{MA}$ and then the earliest stages of in-situ nano-precipitate formation. Neutron powder diffraction was performed at the ISIS neutron source at Rutherford Appleton Laboratory, UK, using a High Resolution Powder Diffractometer (HRPD). We performed real-time thermo-diffraction experiments on powder samples, milled by various routes, over a wide temperature range, up to a maximum temperature of $1100^{\circ} \mathrm{C}$. The penetration depth of neutrons ( $\sim 25 \mathrm{~mm}$ for iron-based alloys) [15] is much larger than 
that $(\sim 5 \mu \mathrm{m})$ of X-rays [16], and allows more representative insights of fine-scale microstructural evolution. Specimens for neutron diffraction were the unconsolidated feedstock and milled powders directly, and so no artefacts were introduced during sample preparation or due to consolidation effects. Because the nano-precipitates formed by annealing the as-milled powders in vacuum are almost identical to those formed at the same temperature but under pressure during HIP consolidation routes [11], we expect that this insitu annealing of the MA powder at temperatures between $800^{\circ} \mathrm{C}$ and $1100^{\circ} \mathrm{C}$ can be used as an analogue to study evolution of the oxide clusters and particles during the HIP process itself. However, the standard $\mathrm{Y}_{2} \mathrm{O}_{3}$ content $(<0.5 \%)$ in ODS alloys is too small to be detected and analysed with confidence by diffraction-based techniques and therefore a higher $\mathrm{Y}_{2} \mathrm{O}_{3}$ concentration $(10 \%)$ was used to prepare $\mathrm{Fe}-14 \mathrm{Cr}-10 \mathrm{Y}_{2} \mathrm{O}_{3}$ ODS powder. As we show, even at such high loadings, complete dissolution during MA was achieved. To support diffraction data, annealed powder was also examined by high magnification scanning electron microscopy (SEM) to reveal the nano-precipitates. The evolution of powder microhardness and microstructure during MA and subsequent $\mathrm{Y}_{2} \mathrm{O}_{3}$ re-precipitation are also presented and the changes in hardness are rationalized in terms of the phase fractions present, the degree of cold work and the extent of annealing.

\section{Experimental}

ODS ferritic steel powder with nominal composition $\mathrm{Fe}-14 \mathrm{Cr}-10 \mathrm{Y}_{2} \mathrm{O}_{3}$ was prepared by MA from a mixture of Ar gas-atomized pre-alloyed Fe-14Cr powder $(<150 \mu \mathrm{m}$, Aubert \& Duval, France) and $\mathrm{Y}_{2} \mathrm{O}_{3}$ powder, ranging in diameter between $20 \mathrm{~nm}$ and $40 \mathrm{~nm}$ (Pi-Kem Ltd, UK) in high purity (99.999\%) Ar. MA was performed in a planetary mill (Pulverisette 6, Fritsch

$\mathrm{GmbH}$, Germany) using a chrome steel bowl $(500 \mathrm{ml})$ and steel balls $(400 \mathrm{~g}, 10 \mathrm{~mm}$ in 
diameter) at a rotational speed of $250 \mathrm{rpm}$ with a ball-to-powder weight ratio of 10:1. Fe$14 \mathrm{Cr}-10 \mathrm{Y}_{2} \mathrm{O}_{3}$ powder subjected to MA reached a steady microstructural condition after 60 hours of MA, as judged by neutron diffraction measurements (see section 3.1). Powders were then annealed at various temperatures in the HRPD to study the kinetics of nano-precipitate formation.

The neutron diffraction measurements used $15 \mathrm{~g}$ of powder in a vanadium can under vacuum $\left(<5 \times 10^{-4}\right.$ mbar $)$ placed in the in-situ furnace. Powder milled for different times was investigated by neutron diffraction at room temperature and then during annealing at different temperatures between 800 and $1100^{\circ} \mathrm{C}\left( \pm 2^{\circ} \mathrm{C}\right)$ for $1 \mathrm{~h}$. The can was heated at a constant rate of $15^{\circ} \mathrm{C} / \mathrm{min}$. Diffraction data were collected from the powder in back-scattering mode over a 0.085-0.390 $\mathrm{nm}$ range in $d$-space both at high temperature and after cooling to room temperature. Crystallite size and lattice strain were determined from diffraction patterns of both as-milled and annealed powder at room temperature, using Williamson-Hall methods via Rietvield refinement, as programmed in the GSAS suite $[17,18]$.

Annealed powders were mounted with epoxy resin, polished, and etched with 3:1:1 ratio of hydrochloric, nitric and acetic acid for 15 seconds. The microstructures of cross-sections were observed by field emission SEM (JSM-840F). The average size of the nano-precipitates was determined by the mean linear intercept method from at least three SEM images in each case, with more than a hundred particles in each image.

Diamond pyramid hardness measurements (minimum 10 per condition) were performed at room temperature on as-milled and annealed powders using a Vickers microhardness tester 
(Model 401/402MVD, Wilson Instruments, USA) at a load of $25 \mathrm{~g}$ for $20 \mathrm{~s}$ on powder crosssections polished to a $0.04 \mu \mathrm{m}$ finish using colloidal silica.

\section{Result and discussion}

\subsection{Neutron diffraction of Fe-14Cr-10Y ${ }_{2} \mathrm{O}_{3}$ powder during MA and in-situ annealing}

The crystal structure evolution of $\mathrm{Fe}-14 \mathrm{Cr}-10 \mathrm{Y}_{2} \mathrm{O}_{3}$ powder as a function of milling time according to neutron diffraction is shown in Fig. 1, with diffraction data from the starting prealloyed $\mathrm{Fe}-14 \mathrm{Cr}$ and $\mathrm{Y}_{2} \mathrm{O}_{3}$ powders included for reference. The two most intense $\mathrm{Y}_{2} \mathrm{O}_{3}$ peak positions from as-supplied $\mathrm{Y}_{2} \mathrm{O}_{3}$ were at $d=0.187$ and $0.306 \mathrm{~nm}$, and are indicated by the vertical lines. The mixed but not milled $\mathrm{Fe}-14 \mathrm{Cr}+\mathrm{Y}_{2} \mathrm{O}_{3}$ powder $(0 \mathrm{~h}$ milled $)$ showed diffraction peaks from both bcc ferrite and cubic $\mathrm{Y}_{2} \mathrm{O}_{3}$, and there was a progressive decrease in peak intensity and increased peak broadening for both phases as milling time increased. The peak broadening can be attributed to the well-known effects of decreasing crystallite size and increasing lattice strain, arising from crystal defects accumulated during the cold work associated with MA [19]. Even with $10 \mathrm{wt} \%$, the $\mathrm{Y}_{2} \mathrm{O}_{3}$ diffraction peak disappeared almost completely after $12 \mathrm{~h}$ milling. It was possible that at this stage undissolved $\mathrm{Y}_{2} \mathrm{O}_{3}$ particles may have remained in the microstructure but were now simply too small to be detected [16]. However, after $60 \mathrm{~h}$ there were no resolvable $\mathrm{Y}_{2} \mathrm{O}_{3}$ peaks, which we assume to be a consequence of the $\mathrm{Y}_{2} \mathrm{O}_{3}$ particles being dissociated and finally dissolved in the $\mathrm{Fe}-14 \mathrm{Cr}$ matrix [11]. Segregation of $\mathrm{Y}$ dissociated from $\mathrm{Y}_{2} \mathrm{O}_{3}$ during MA might be expected to be concentrated at grain boundaries, but Y segregation to the many dislocations in such a highly strained material can also be expected. Atom probe studies (the only true atomic resolution microscopy) have recently confirmed the formation of a relatively homogeneous 
supersaturated solid solution containing $\mathrm{Y}$ and $\mathrm{O}$ with extremely low levels of grain boundary segregation, and supporting the relatively homogeneous dissolution of $\mathrm{Y}_{2} \mathrm{O}_{3}$ during mechanical alloying [6]. Compared with atom probe tomography (or transmission electron microscopy) of as-milled powders, the present paper samples many orders of magnitude higher volumes of material, and shows for the first time important consistency between high resolution but time-consuming studies on tiny volumes of materials and this more representative and faster study by neutron diffraction. The thermodynamic driving force for $\mathrm{Y}_{2} \mathrm{O}_{3}$ dissolution is an overall reduction of the free energy provided by a single solution of Fe-Cr-Y-O over a highly defective ferritic matrix containing fine $\mathrm{Y}_{2} \mathrm{O}_{3}$ particles with an increasing interfacial energy as milling progresses [3]. Kinetically, the dissolution into the ferrite is facilitated by small crystallite sizes and a high vacancy and dislocation density $[20,21]$.

When the yttrium and oxygen atoms from disassociated $\mathrm{Y}_{2} \mathrm{O}_{3}$ were dissolved substitutionally and interstitially in the bcc crystalline lattice of ferrite during MA, distortion of the lattice might be expected because of the atomic misfit between $\mathrm{Y}$ and $\mathrm{Fe}$ (atomic radius: $\mathrm{Y}=0.182$ $\mathrm{nm} ; \mathrm{Fe}=0.124 \mathrm{~nm}$ ) [3]. However, there was no discernible shift in the ferrite peak positions in Fig. 1. Similar results have been previously reported $[3,10,22,23]$, and the comparative insensitivity of the lattice parameters can be attributed to:

1) Any increase in lattice parameter of as-milled powder induced by dissolved $Y$ and $O$ is partially relieved by a decrease in lattice parameter induced by the formation of a high concentration of lattice vacancies during long-time MA [23]; and 
2) The diffraction peaks of ferrite from as-milled powder were significantly broadened due to decreasing crystallite size and increasing lattice strain, and this makes any underlying peak shifts very difficult to identify [19].

Fig. 2 shows the in-situ high temperature neutron diffraction traces of the Fe- $14 \mathrm{Cr}-10 \mathrm{Y}_{2} \mathrm{O}_{3}$ MA powder after annealing for $1 \mathrm{~h}$ at various temperatures in the range $800-1100^{\circ} \mathrm{C}$. Three room temperature traces are also included for comparison: the upper two patterns from MA powder with milling times of $0 \mathrm{~h}$ and $60 \mathrm{~h}$; and a lower pattern from powder annealed at $1100^{\circ} \mathrm{C}$ for $1 \mathrm{~h}$ and cooled to room temperature. The powder annealed at $800^{\circ} \mathrm{C}$ for $1 \mathrm{~h}$ showed no marked change from the as-milled powder, whereas at $900^{\circ} \mathrm{C}$ an fcc austenite peak developed. Since the nominal $14 \mathrm{wt} \% \mathrm{Cr}$ content was higher than the minimum of 12.7 $w t \%$ [24] required for a fully ferritic microstructure at all temperatures of interest, the formation of austenite might be attributed to the presence of background carbon and nitrogen austenite stabilisers accumulated from the atomisation and ball milling steps [25]. Reprecipitation of $\mathrm{Y}_{2} \mathrm{O}_{3}$ also started at $900^{\circ} \mathrm{C}$ as shown by the broad peaks at $d \sim 0.187$ and $0.306 \mathrm{~nm}$, the intensity of which increased with increasing annealing temperature above $1000^{\circ} \mathrm{C} . \mathrm{YCrO}_{3}$ was also formed above $1000^{\circ} \mathrm{C}$, and was consistent with coexistence with $\mathrm{Y}_{2} \mathrm{O}_{3}$ above $1300 \mathrm{~K}$ as shown in the ternary $\mathrm{Y}-\mathrm{Cr}-\mathrm{O}$ phase diagram [26]. Any high temperature austenite fully transformed to ferrite on cooling, and both $\mathrm{Y}_{2} \mathrm{O}_{3}$ and $\mathrm{YCrO}_{3}$ were retained. There was a shift in diffraction peak position for $\mathrm{Y}_{2} \mathrm{O}_{3}$ precipitates and the matrix ferrite toward higher $d$ values in comparison with unmilled powder because of thermal residual strains. 
Since re-precipitation of $\mathrm{Y}_{2} \mathrm{O}_{3}$ started at $900^{\circ} \mathrm{C}$, re-precipitation kinetics as a function of time during isothermal annealing at $900^{\circ} \mathrm{C}$ were studied, with powder neutron diffraction patterns recorded repeatedly at 5 min intervals. A selection of the patterns is shown in Fig. 3, again with the patterns for $0 \mathrm{~h}$ and $60 \mathrm{~h}$ as-milled powder for comparison. Austenite was first resolved after $50 \mathrm{~min}$ and re-precipitation of $\mathrm{Y}_{2} \mathrm{O}_{3}$ was first resolved after $60 \mathrm{~min}$. The peak intensity for austenite and $\mathrm{Y}_{2} \mathrm{O}_{3}$ increased with annealing time, and was then unchanged after 120 min at $900^{\circ} \mathrm{C}$. At $1000^{\circ} \mathrm{C}$, nano-precipitate formation was much more rapid and after only $5 \mathrm{~min}$ the patterns resembled those for $60 \mathrm{~min}$ at $900^{\circ} \mathrm{C}$. Consequently, the temperature range $900-1000^{\circ} \mathrm{C}$ is the practical range for re-precipitation control, with precipitation kinetics spanning approximately an order of magnitude across this interval.

\subsection{Precipitate morphology}

Cross-sectional secondary electron SEM images of etched surface from $\mathrm{Fe}-14 \mathrm{Cr}-10 \mathrm{Y}_{2} \mathrm{O}_{3}$ powders annealed at different temperatures ranging from 800 to $1100^{\circ} \mathrm{C}$ for $1 \mathrm{~h}$ are shown in Fig. 4. No features or precipitates (except pores) were resolved after annealing at $800^{\circ} \mathrm{C}$, as shown in Fig. 4(a). Fig. 4(b) shows that annealing at $900^{\circ} \mathrm{C}$ led to the formation of $5-50 \mathrm{~nm}$ particles, with an average diameter of $10 \mathrm{~nm}$. As the neutron diffraction patterns in Fig. 2 and 3 showed $\mathrm{Y}_{2} \mathrm{O}_{3}$ at $900^{\circ} \mathrm{C}$, these precipitates are likely to be $\mathrm{Y}_{2} \mathrm{O}_{3}$. Fig. 4(c) shows powders annealed at $1100^{\circ} \mathrm{C}$ for $1 \mathrm{~h}$ with a much higher fraction of precipitates (an average diameter of $\sim 25 \mathrm{~nm}$ ); here neutron diffraction indicated the presence of $\mathrm{Y}_{2} \mathrm{O}_{3}$ and $\mathrm{YCrO}_{3}$.

\subsection{Microhardness, crystallite size and lattice strain of powder during processing}


Figure 5 correlates changes in microhardness, crystallite size and lattice strain of the Fe$14 \mathrm{Cr}-10 \mathrm{Y}_{2} \mathrm{O}_{3}$ powder with milling time and annealing temperature. Although there are likely to be errors induced by the curve-fitting process in the absolute values of crystallite size and lattice strain, the trend of changes with process conditions was consistent and monotonic. During the early stages of milling $(<12 \mathrm{~h})$, the microhardness of MA powder increased rapidly with milling time, and can be ascribed to a reduction of grain size and increasing work hardening, as evidenced by the decrease in crystallite size and increase in lattice strain in Fig. 5(a). Beyond 12 h, microhardness increased only slowly, reaching a plateau of 771 $\mathrm{kg} / \mathrm{mm}^{2}$ after $60 \mathrm{~h}$. The stability of microhardness corresponded to the gradual stabilisation of both crystallite size at $\sim 20 \mathrm{~nm}$ and lattice strain at $\sim 0.89 \%$ after $30 \mathrm{~h}$. We propose that the defect or dislocation density in the powder had stabilised at this stage because a quasiequilibrium had been established between the rate of dislocation accumulation (work hardening) and rate of thermally induced recovery [27]. Fig. 5(b) shows the variation of microhardness, crystallite size and lattice strain of the Fe- $14 \mathrm{Cr}-10 \mathrm{Y}_{2} \mathrm{O}_{3}$ powder after $60 \mathrm{~h}$ MA and annealing at different temperatures for $1 \mathrm{~h}$. In general, the crystallite size increased, and the microhardness and lattice strain decreased with increasing annealing temperature. Compared with the $60 \mathrm{~h}$ as-milled powder, powder annealed at $800^{\circ} \mathrm{C}$ had a slightly higher microhardness (816 vs $771 \mathrm{~kg} / \mathrm{mm}^{2}$ for as-milled powder), almost the same crystallite size $(\sim 20 \mathrm{~nm})$, but much smaller lattice strain $(0.41 \%$ vs $0.89 \%$ for as-milled powder $)$. The reduction in lattice strain is likely to be associated with recovery/recrystallization processes, as reported for both powder and $\mathrm{HIPed} \mathrm{Fe}-14 \mathrm{Cr}-0.25 \mathrm{Y}_{2} \mathrm{O}_{3}$ processed at similar temperatures [28]. We suggest that the high hardness in as-milled powder, even after annealing at $800^{\circ} \mathrm{C}$ for $1 \mathrm{~h}$, arises because: 
1) The hardness of MA powder after annealing mainly depends on the crystallite size rather than the lattice strain [27]; and

2) Although no nano-precipitates were detected at $800^{\circ} \mathrm{C}$ (Fig. 2), extremely fine $(<5 \mathrm{~nm})$ nanoclusters may have already started to form, as suggested by recent small angle neutron scattering and atom probe tomography studies on ODS ferritic steels $[8,12]$.

Above $800^{\circ} \mathrm{C}$, oxide nano-precipitates were detected by neutron diffraction and their coarsening started as evidenced by SEM images in Fig 4. The crystallite size of annealed powder increased dramatically with increasing annealing temperature and was up to $272 \mathrm{~nm}$ for powder annealed at $1100^{\circ} \mathrm{C}$ for $1 \mathrm{~h}$. Crystallite sizes of up to $1000 \mathrm{~nm}$ have been reported previously in powders produced by MA on the basis of HRPD data performed on the same diffractometer [29], which agreed with crystallite data obtained by XRD from the same powder. Therefore, crystallite sizes up to $272 \mathrm{~nm}$ obtained from neutron line-broadening data in this work are well within the range of the technique. Obviously, re-precipitation of nanooxides coincided with the growth of matrix grains [3], and the coarsening of both matrix grains and nano-precipitates gives rise to lower values of powder microhardness.

The change in crystallite size from approximately 20 to $272 \mathrm{~nm}$ in Fig. 5(b) did not produce a large decrease (only 25\%) in hardness, as might be expected from the "normal" Hall-Petch relationship, because nanocrystalline materials very often show decreased microhardnesses when compared with predictions of Hall-Petch type relationships that are obtained for much coarser-grained materials [30]. 
In summary, this work reveals insights into both the kinetics of $\mathrm{Y}_{2} \mathrm{O}_{3}$ dissolution and the very beginning of its re-precipitation as nanoclusters, for the first time based on bulk information from ODS powders using in-situ high resolution powder neutron diffraction. The nucleation of nano-precipitates started at $800-900^{\circ} \mathrm{C}$ and significant coarsening started only above $900^{\circ} \mathrm{C}$, providing information on the processing window for controlled nano-precipitate size and density, and thus the performance of ODS steels.

\section{Conclusions}

Microstructural evolution and its relationship with hardness (related to yield strength) in Fe$14 \mathrm{Cr}-10 \mathrm{Y}_{2} \mathrm{O}_{3}$ ODS ferritic steel powder during MA and subsequent annealing were studied using neutron diffraction, microscopy and microhardness indentation. $\mathrm{Y}_{2} \mathrm{O}_{3}$ particles were gradually fractured and eventually, after 60 hours milling, almost fully dissolved into the ferrite matrix during MA. The subsequent precipitation and formation of nano-size oxide precipitates were successfully observed for the first time by in-situ powder neutron diffraction. Although a very fine-scale, low fraction precipitation of oxide could not be excluded at $800^{\circ} \mathrm{C}$, distinct precipitation of $\mathrm{Y}_{2} \mathrm{O}_{3}$ was first resolved after $1 \mathrm{~h}$ at $900^{\circ} \mathrm{C}$, along with the coexistence of $\mathrm{YCrO}_{3}$ and $\mathrm{Y}_{2} \mathrm{O}_{3}$ at annealing temperatures of $1000^{\circ} \mathrm{C}$ and above. Microscopy of annealed powders confirmed coarsening of nano-precipitates with increasing annealing temperature. Powder microhardness variations have been rationalised in terms of the changes in phase, lattice strain, crystallite and nano-precipitate size evolution during annealing.

\section{Acknowledgements}


This work was financially supported by the UK Engineering and Physical Sciences Research Council under grants EP/H018921/1 and EP/I003282/1. We are also grateful to the UK Science and Technology Facilities Council for beam-time awards RB1120130 and RB1220077 at the ISIS facility. We thank Dr Kevin Knight and Dr Aziz Daoud-Aladine for their support during the HRPD experiments. MEF is supported by the Lloyd's Register Foundation, which supports the advancement of engineering-related education, and funds research and development that enhances safety of life at sea, on land and in the air.

\section{References}

[1] G.R. Odette, M.J. Alinger, B.D. Wirth, Annu. Rev. Mater. Res. 38 (2008) 471-503.

[2] C. Cayron, E. Rath, I. Chu, S. Launois, J. Nucl. Mater. 335 (2004) 83-102.

[3] Y. Kimura, S. Takaki, S. Suejima, R. Uemori, and H. Tamehiro, ISIJ International. 39 (1999) 176-182.

[4] T. Okuda, and M. Fujiwara, J. Mater. Sci. Lett. 14 (1995) 1600-1603.

[5] M.K. Miller, K.F. Russell, D.T. Hoelzer, J. Nucl. Mater. 351 (2006) 261-268.

[6] M. K. Miller, C. L. Fu, M. Krcmar, D. T. Hoelzer, and C. T. Liu, Front. Mater. Sci. China. 3 (2009) 9-14.

[7] D.J. Larson, P.J. Maziasz, I.-S. Kim, K. Miyahara, Scripta Mater. 44 (2001) 359-364.

[8] M. Laurent-Brocq, F. Legendre, M.-H. Mathon, A. Mascaro, S. Poissonnet, B. Radiguet, P. Pareige, M. Loyer, O. Leseigneur, Acta Mater. 60 (2012) 7150-7159. 
[9] M.K. Miller, E.A. Kenik, K.F. Russell, L. Heatherly, D.T. Hoelzer, P.J. Maziasz, Mater. Sci. Eng. A. 353 (2003) 140-145.

[10] L. Toualbi, M. Ratti, G. André, F. Onimus, Y. de Carlan, J. Nucl. Mater. 417 (2011) 225-228.

[11] M.J. Alinger, G.R. Odette, D.T. Hoelzer, J. Nucl. Mater. 329-333 (2004) 382-386.

[12] M.J. Alinger, G.R. Odette, D.T. Hoelzer, Acta Mater. 57 (2009) 392-406.

[13] S.Y. Zhong, J. Ribis, V. Klosek, Y. de Carlan, N. Lochet, V. Ji, M.H. Mathon, J. Nucl. Mater. 428 (2012) 154-159.

[14] P. He, T. Liu, A. Möslang, R. Lindau, R. Ziegler, J. Hoffmann, P. Kurinskiy, L. Commin, P. Vladimirov, S. Nikitenko, M. Silveir, Mater. Chem. Phys. 136 (2012) 990998.

[15] W. Woo, V. Em, P. Mikula, G.B. An, B. S. Seong, Mater. Sci. Eng. A. 528 (2011) 4120-4124.

[16] A. Ramar, Z. Oksiuta, N. Baluc, R. Schäublin, Fusion Eng. Design. 82 (2007) 25432549 .

[17] G.K. Williamson, W.H. Hall, Acta Metall. 1 (1953) 22-31.

[18] A.C. Larson, R.B. Von Dreele, General structure analysis systems GSAS, Los Alamos National Laboratory Report, 2001.

[19] C. Suryanarayana, Prog. Mater. Sci. 46 (2001) 1-184.

[20] Y. Jiang, J. R. Smith, and G. R. Odette, Phys. Rev. B. 79 (2009) 064103.

[21] L. S. Vasil'ev and S. F. Lomayeva, J. Mater. Sci. 39 (2004) 5411-5415.

[22] M.P. Phaniraj, D. Kim, J. H. Shim, Y. W. Cho, Acta Mater. 57 (2009) 1856-1864. 
[23] M. Brocq, B. Radiguet, J.-M. Le Breton, F. Cuvilly, P. Pareige, and F. Legendre, Acta Mater. 58 (2010) 1806-1814.

[24] M.J. Alinger, On the formation and stability of nanometer scale precipitates in ferritic alloys during processing and high temperature service. Ph.D thesis, University of California, Santa Barbara, 2004.

[25] P. Olier, J. Malaplate, M.H. Mathon, D. Nunes, D. Hamon, L. Toualbi, Y. de Carlan, L. Chaffron, J. Nucl. Mater. 428 (2012) 40-46.

[26] K.-I. Kawamura, T. Maruyama, K. Nagata, Metall. Mater. Trans. B. 26 (1995) 289-294.

[27] Y. Kimura, H. Hidaka, and S. Takaki, Mater. Trans. JIM. 40 (1999) 1149-1157.

[28] H. Kishimoto, M.J. Alinger, G.R. Odette, T. Yamamoto, J. Nucl. Mater. 329-333 (2004) 369-371.

[29] S. Enzo, R. Frattini, G. Mulas, and G. Principi, J. Mater. Sci. 39 (2004) 6333-6339.

[30] X.D. Liu, M. Nagumo, and M. Umemoto, Mater. Trans. JIM. 38 (1997) 1033-1039. 


\section{Figure captions}

Fig. 1 Neutron diffraction patterns of $\mathrm{Fe}-14 \mathrm{Cr}-10 \mathrm{Y}_{2} \mathrm{O}_{3}$ powder as a function of MA times.

Fig. 2 In-situ neutron diffraction patterns of $\mathrm{Fe}-14 \mathrm{Cr}-10 \mathrm{Y}_{2} \mathrm{O}_{3}$ powder measured during annealing at different temperatures for $1 \mathrm{~h}$.

Fig. $3 \mathrm{In}$-situ neutron diffraction patterns of $\mathrm{Fe}-14 \mathrm{Cr}-10 \mathrm{Y}_{2} \mathrm{O}_{3}$ powder measured during $900^{\circ} \mathrm{C}$ annealing at different times.

Fig. 4 SEM images of polished and etched surfaces from $\mathrm{Fe}-14 \mathrm{Cr}-10 \mathrm{Y}_{2} \mathrm{O}_{3}$ powder annealed at different temperatures for $1 \mathrm{~h}$ : (a) $800^{\circ} \mathrm{C}$; (b) $900^{\circ} \mathrm{C}$; and (c) $1100^{\circ} \mathrm{C}$.

Fig. 5 Variation of microhardness, crystallite size and lattice strain of $\mathrm{Fe}-14 \mathrm{Cr}-10 \mathrm{Y}_{2} \mathrm{O}_{3}$

powder during processing: (a) as a function of milling time; (b) as a function of annealing temperatures. 


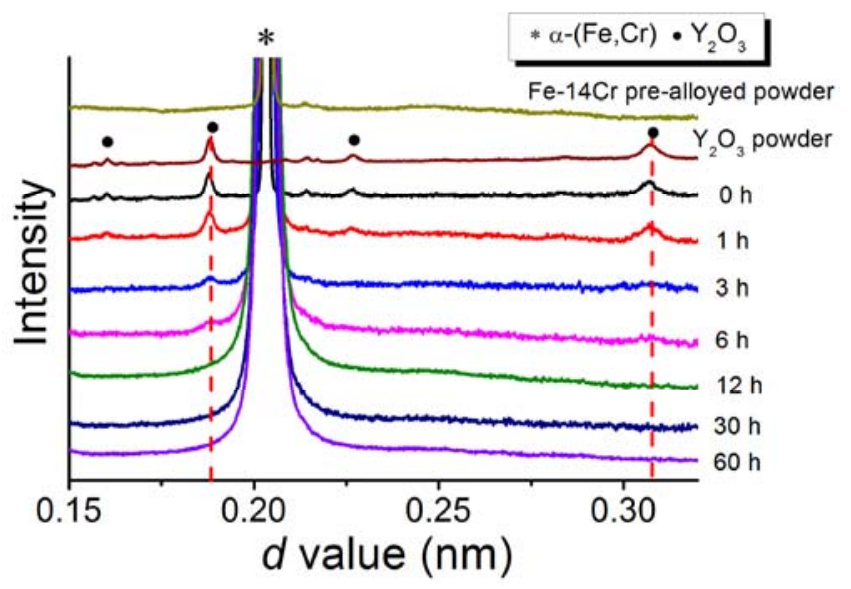

Fig. 1

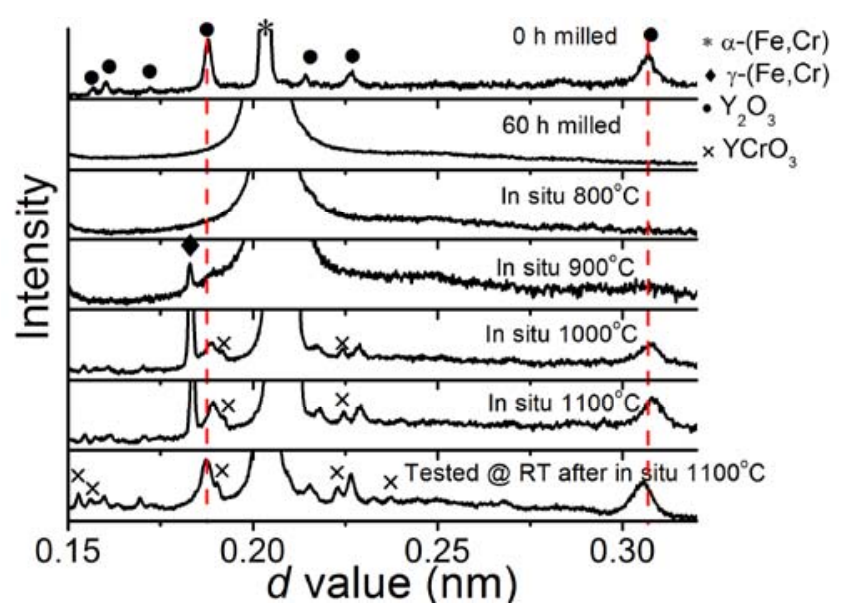

Fig. 2

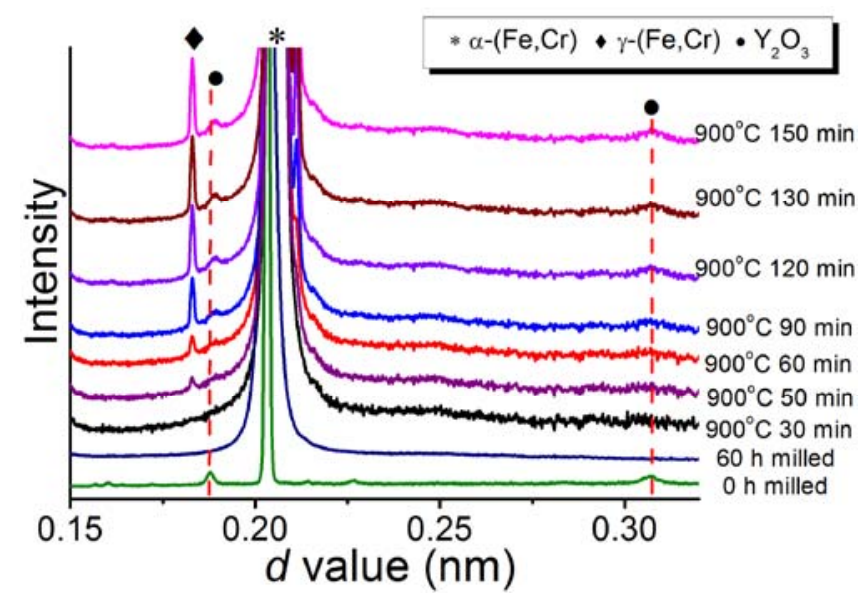

Fig. 3 

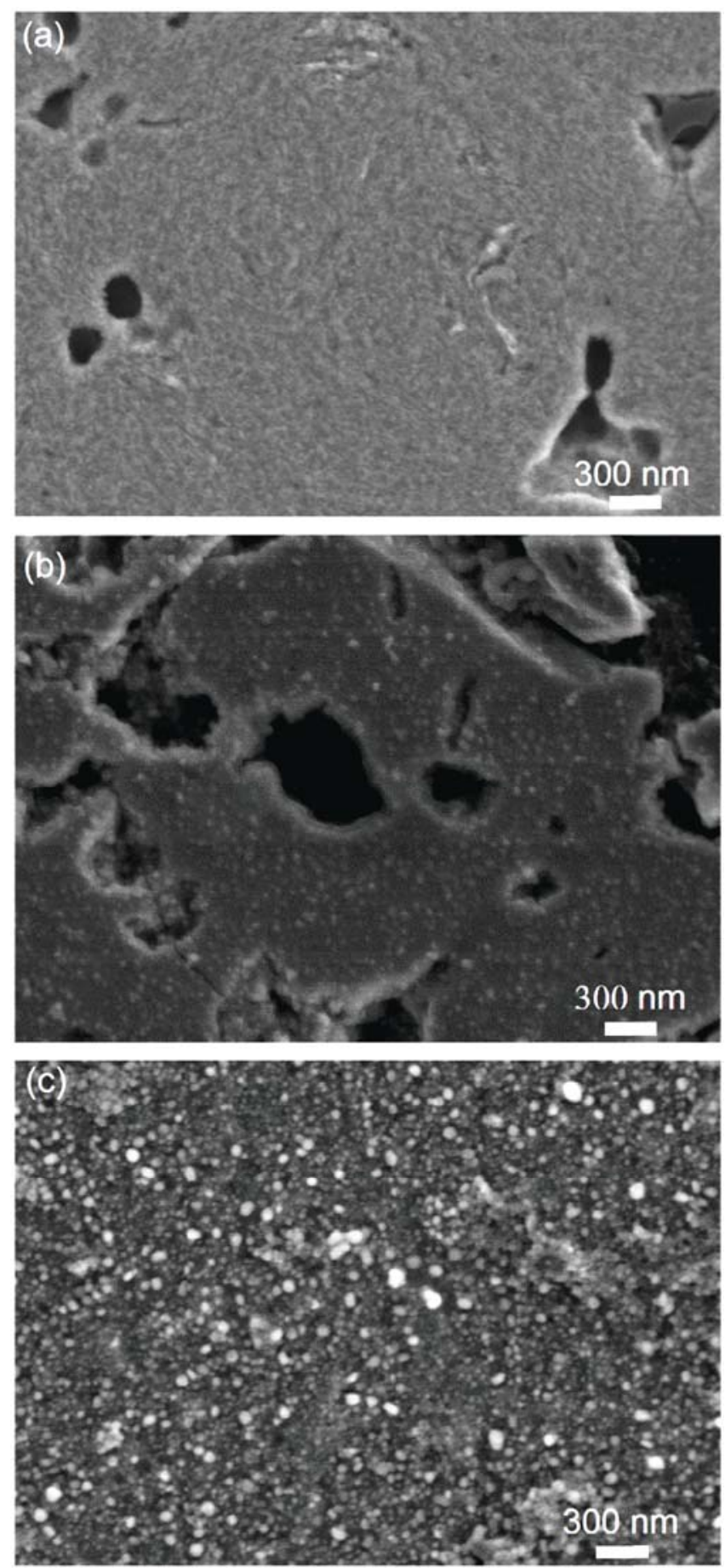

Fig. 4 

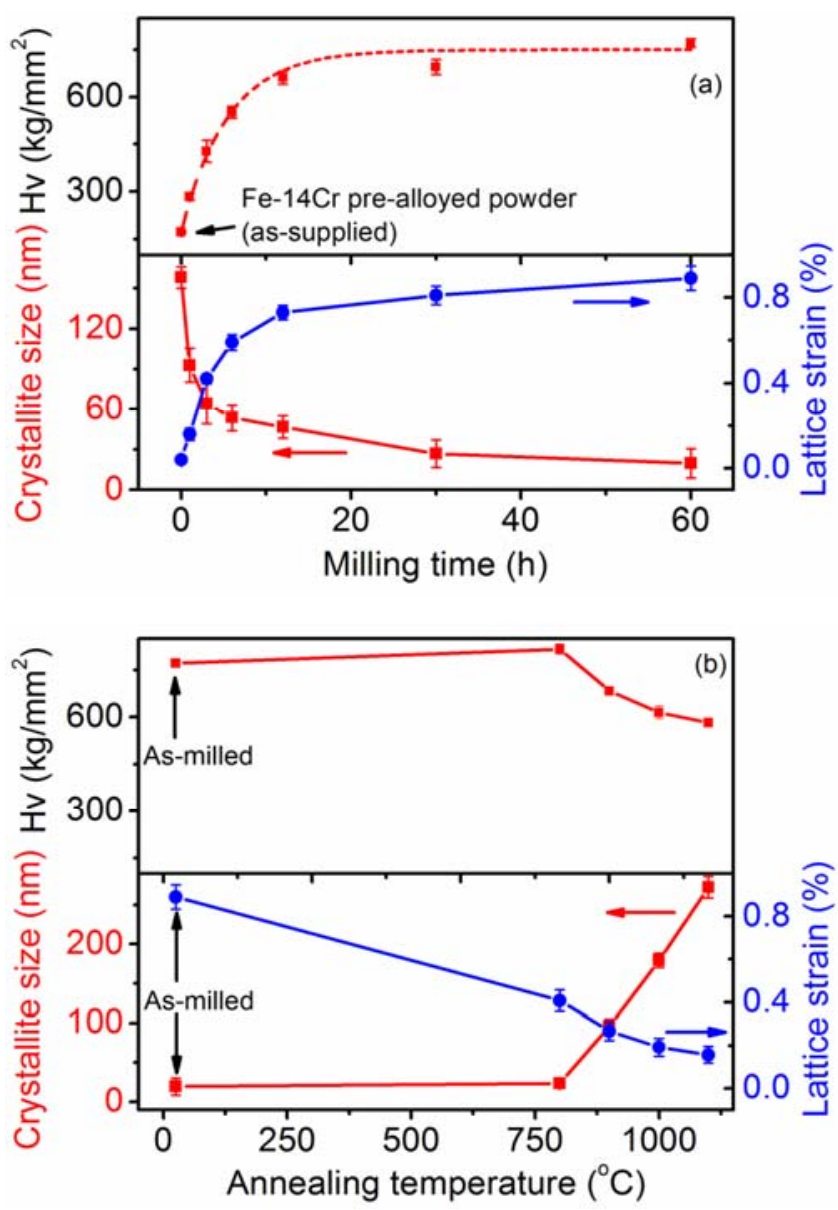

Fig. 5 